Miles, A. A. (1951). J. gen. Microbiol. 5, 307-316.

\title{
The Mouse Pathogenicity and Toxicity of Proteus vulgaris
}

\author{
By A. A. MILES \\ National Institute for Medical Research, Mill Hill, London N.W. 7
}

SUMMARY: The LD50 for mice of twenty-one strains of Proteus vulgaris from human infection ranged from 2 to 600 million living bacilli. Mouse-virulence was not associated with the severity or the site of infection in the human subject.

The relatively high virulence of some strains was not due to any peculiar demonstrable toxicity of the cell-substance, because killed cells of high and low virulent strains were about equally toxic. The toxicity appeared to reside in a predominantly lipo-polysaccharide fraction, immunologically similar to the antigen characterizing the somatic surface of recently isolated strains.

This investigation was made to find whether strains of Proteus vulgaris isolated from infections in man could be distinguished by a laboratory virulence test, and whether virulence could be correlated with any other microbiological character of the strains.

\section{MATERIALS AND METHODS}

For the purposes of this paper the name Pr. vulgaris is used for all ureasepositive, swarming strains of the Proteus group, withholding the distinction of Pr. vulgaris and Pr. mirabilis until the specific status of these two groups is more firmly established (Topley \& Wilson, 1946, p. 649).

Source and properties of the strains. Twenty-one strains of Pr. vulgaris were isolated either from the urine of patients with pyelitis or cystitis or from the pus found in various situations-the mastoid antrum, lung and pleural abscesses, and acutely infected surgical wounds. No strain was included in the survey unless it was either the sole or the predominant organism on blood and MacConkey agar plates seeded directly with the pus or a spun deposit of the urine; that is, unless it gave at least this indication of being the chief cause of the infective lesion from which it was isolated. The strains were maintained in stab-cultures in nutrient broth $+0.75 \%$ agar, in which they could be stored for several months in the cold $\left(2^{\circ}-8^{\circ}\right)$ without subculture.

All strains swarmed on nutrient $2 \%$ agar media. They fermented glucose rapidly with production of acid and gas, but did not ferment mannitol, lactose, arabinose, dulcitol, inositol, rhamnose. All but PR 8 and PR 24 (see below) slowly produced acid from sucrose and salicin: and all but PR 14 fermented xylose in 2-5 days with the production of acid and gas; PR 14 produced slight acid from xylose in 10 days.

All strains produced slight acid, then marked alkali and peptonization in litmus milk, liquefied gelatin rapidly, digested Loeffler's coagulated serum medium, and were catalase, nitratase, urease and $\mathrm{H}_{2} \mathrm{~S}$ positive. The utilization of citrate in Koser's medium was variable. Except PR 5, none fermented maltose or produced indole and all produced acetylmethylcarbinol tested by 
Barritt's (1936) method; PR5 fermented maltose, was indole-positive and Voges-Proskauer negative.

PR 5 falls therefore into the group 'Pr. vulgaris Hauser' and the rest into the group 'Pr. mirabilis Hauser'.

Virulence tests; calculation of the LD50. Within 1-2 weeks of isolating the strain, overnight subcultures from the stock stab cultures, in nutrient broth at $37^{\circ}$, were tested in $18-22 \mathrm{~g}$. mice by intraperitoneal injection of $0.25 \mathrm{ml}$. graded ten-fold dilutions. Four or six mice per dose were used. At the same time a 6-drop viable count was made on MacConkey agar plates by the method of Miles \& Misra (1938). Only those deaths accompanied by a bacteraemia with Pr. vulgaris cultivable from the heart blood on direct plating were recorded. All such deaths occurred within 7 days of injection. The virulence was measured by the LD50, estimated by Gaddum's (1933) method. The method was not strictly applicable to some of the results obtained. Thus in six of the titrations the tenfold grading of doses was too coarse, one dose killing no mice, and ten times the dose, all the mice (e.g. Table $1 a$, PR9). In these cases the LD 50 was estimated on the assumption that the highest non-killing dose was the maximum LD 0, that the lowest dose killing all the mice was the minimum LD 100, and that the intermediate $\mathrm{LD}$ values were distributed normally between these limits. In two titrations, PR 23 (Table $1 a$ ) and PR 24, the highest dose killed no mice; here the LD50 is recorded as greater than the highest dose given, and (in brackets) as an LD50 estimated on the assumption that this dose was the maximum LD 0 and that a dose 10 times as great would have killed all the mice, and was the minimum LD 100. In all these cases, therefore, the LD 50, recorded in Table $1 b$ in ordinary type, can be regarded only as a very approximate measure of virulence; no estimation of the error is justifiable. For the remaining fifteen titrations, the responses were like those to PR1 (Table 1a) and both LD 50 and the approximate error are recorded in Table $1 b$ in heavy type.

Toxicity tests. The toxicity of whole killed bacilli, and of fractions derived therefrom, was estimated by intraperitoneal injection of graded doses in 18-22 $\mathrm{g}$. mice, and Gaddum's method for calculating the LD50 applied.

Precipitin tests were made by adding $0.3 \mathrm{ml}$. of a given concentration of rabbit antiserum against somatic antigens to $0.3 \mathrm{ml}$. of three-fold dilutions of antigen, and reading the end-point of just visible precipitation after $3 \mathrm{hr}$. at $50^{\circ}$ and overnight on the bench.

\section{RESULTS}

\section{Virulence of recently isolated strains}

Table $1 b$ records the source and the approximate LD50 of the twenty-one strains. Though estimates are crude it is clear that virulence varies widely; and from column 2, that neither urinary nor pus strains were peculiarly virulent. The different estimations were made upon the laboratory strain of mice over a period of 10 weeks, and may be considered reasonably comparable, though not as comparable as would be the case had all strains been tested simultaneously on a single large batch of mice. (The strains were numbered in order of virulence estimated by inspection of the death rates. PR3 and PR 17 
The mouse pathogenicity and toxicity of Proteus vulgaris 309

particularly are out of place because in each case a single death with a few bacilli brought down the estimate of the LD50.)

When the strains were isolated, notes were taken of the clinical severity of the infection; the mouse-virulence of the strains was not in any way associated with clinical severity. The LD50 varies from 2 to 600 million living bacteria. Though the dose-response was steep in most cases, it was less steep for one of the most virulent strains, PR 1 (Tables $1 a$ and 2); suggesting that whereas the death was largely toxic in most tests, PR 1 had an invasive capacity not displayed by the other strains.

Table 1a. Examples of coarse titrations of virulence of Proteus strains

$\begin{array}{ccc}\begin{array}{c}\text { Strain } \\ (\text { PR) }\end{array} & \begin{array}{c}\text { Dose of } \\ \text { viable bacilli } \\ \text { (millions) }\end{array} & \begin{array}{c}\text { No. of mice } \\ \text { dying/group }\end{array} \\ 1 & 75 \cdot 00 & 6 / 6 \\ & 7 \cdot 50 & 4 / 6 \\ 9 & 0 \cdot 75 & 1 / 6 \\ & 47 \cdot 00 & 6 / 6 \\ & 4 \cdot 70 & 0 / 6 \\ 23 & 0 \cdot 47 & 0 / 6 \\ & 125 \cdot 00 & 0 / 4 \\ & 12 \cdot 50 & 0 / 4 \\ & 1 \cdot 25 & 0 / 4\end{array}$

Table $1 b$. The LD50 in mice of twenty-one urinary and pus strains of Proteus spp.

\begin{tabular}{|c|c|c|}
\hline \multirow[b]{2}{*}{ Strain } & \\
\hline & Source & $\begin{array}{l}\text { LD50 and approx. } \\
\text { error (millions) }\end{array}$ \\
\hline 1 & $\begin{array}{l}\text { Urine } \\
\text { Urine }\end{array}$ & $\begin{array}{l}2 \cdot 28 \pm 0 \cdot 87 \\
0 \cdot 23+0.00128\end{array}$ \\
\hline $\begin{array}{l}3 \\
4\end{array}$ & Urine & $10 \cdot 6 \pm 0.00081$ \\
\hline 5 & Pus & $11 \cdot 0$ \\
\hline 7 & Pus & $13 \cdot 0$ \\
\hline 8 & Urine & $11.7 \pm 0.0057$ \\
\hline 9 & Pus & $44 \cdot 0$ \\
\hline 10 & Pus & $15 \cdot 0$ \\
\hline 11 & Urine & $15 \cdot 8 \pm 0.0077$ \\
\hline 12 & Urine & $17 \cdot 0 \pm 0.0083$ \\
\hline 13 & Pus & $22.0 \pm 0.001$ \\
\hline 15 & Urine & $20.8 \pm 0.0485$ \\
\hline 16 & Urine & 24.6 \\
\hline 17 & Urine & $0 \cdot 37 \pm 0.0457$ \\
\hline 18 & Urine & $52.4 \pm 0.00105$ \\
\hline 19 & Pus & $63.0 \pm 0.007$ \\
\hline 20 & Urine & 93.0 \\
\hline 21 & Pus & $55 \cdot 0 \pm 0.00153$ \\
\hline 22 & Urine & $160 \cdot 0$ \\
\hline 23 & Urine & $>56(160.0)$ \\
\hline 24 & Pus & $>125(625.0)$ \\
\hline
\end{tabular}

Comparison of strains of presumed high and low virulence

The relation between the capacity to invade and to multiply in the body, and the gross toxicity of the bacilli, was explored in greater detail in a comparison of the two most virulent and the two least virulent strains-PR 1, PR3, PR 23 and PR 24. 
Eighteen-hour cultures from the heart blood of mice dead from infection by the strains were seeded on to nutrient agar in Roux bottles, and the cells harvested after $18 \mathrm{hr}$. growth at $37^{\circ}$. They were washed twice by centrifugation in sterile Ringer's solution and half of each suspension heated for $90 \mathrm{~min}$. at $60^{\circ}$. These heated suspensions, which were subsequently proved to have been sterile, and the corresponding living suspensions were diluted five-fold, and viable counts made of the living suspensions. Samples of each killed suspension were dried over $\mathrm{P}_{2} \mathrm{O}_{5}$ in vacuo, and after due allowance for the contained salts of the Ringer solution, the weight of bacteria/ml. determined. The death-rates for fivefold differences in dose are recorded in Table 2.

Table 2. The LD 50 of living $(L)$ and dead $(D)$ Proteus strains, two (PR1 and PR3) of high, and two (PR23 and 24) of low mouse-virulence.

PR 1

\begin{tabular}{|c|c|c|}
\hline \multirow{2}{*}{$\begin{array}{c}\text { No. } \\
\text { bacilli } \\
\text { (millions) }\end{array}$} & \multicolumn{2}{|c|}{$\begin{array}{l}\text { No. mice } \\
\text { dying/group }\end{array}$} \\
\hline & $\mathbf{L}$ & D \\
\hline 19,840 & - & $6 / 6$ \\
\hline $\mathbf{3 , 9 6 8}$ & - & $2 / 6$ \\
\hline 793 & $6 / 6$ & $0 / 6$ \\
\hline 159 & $6 / 6$ & $0 / 6$ \\
\hline 32 & $4 / 6$ & $0 / 6$ \\
\hline 6 & $2 / 6$ & - \\
\hline 1 & $1 / 6$ & - \\
\hline$\underset{\text { (millions) }}{\operatorname{LD50}}$ & $10 \cdot 8$ & $\begin{array}{c}6925 \\
(\equiv 0.954 \mathrm{mg} .\end{array}$ \\
\hline & R24 & \\
\hline
\end{tabular}

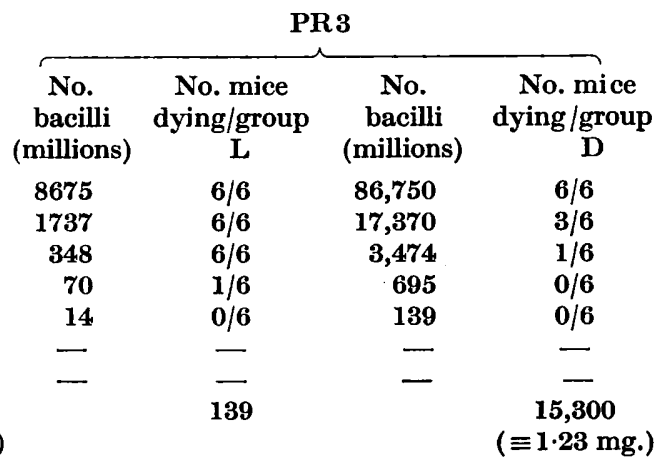

$\begin{array}{cccc}\begin{array}{c}\text { No. } \\ \text { bacilli } \\ \text { (millions) }\end{array} & \begin{array}{c}\text { No. mice } \\ \text { dying/group }\end{array} & \begin{array}{c}\text { No. } \\ \text { bacilli } \\ \text { (millions) }\end{array} & \begin{array}{c}\text { No. mice } \\ \text { dying/group } \\ D\end{array} \\ 3550 & 6 / 6 & 35,500 & 6 / 6 \\ 710 & 5 / 6 & 7,100 & 1 / 6 \\ 142 & 2 / 6 & 1,420 & 0 / 6 \\ 28 & 0 / 6 & 280 & 0 / 6 \\ 6 & 0 / 6 & 57 & 0 / 6 \\ - & - & - & - \\ - & - & - & - \\ & 244 & & 11,350 \\ & & & \end{array}$

These more accurate titrations confirm the relatively high virulence of PR 1, but class PR3 with the low-virulent PR 23 and PR24. The change in PR3 is great enough to suggest a loss of virulence even in the little manipulation and subculture that took place between the first and second tests. The dead bacilli, from the same cultures as the living, were more toxic in PR 1, but the twofold difference is slight compared with the difference in virulence. The LD 50 ratios for dead and living bacilli were: PR 1, 595; PR3, 110; PR 23, 48; PR 24, 91.

The high ratio (595) for PR 1 suggests that this strain is better than the 


\section{The mouse pathogenicity and toxicity of Proteus vulgaris 311}

others in multiplying in the body to the point of lethal intoxication, that is, it is more invasive. It is clear, therefore, in these strains, that toxicity per se is unlikely to be even a partial index of virulence. In any event, the large errors in the titrations suggest that prohibitively large numbers of mice would be required to establish significant differences in virulence.

\section{The lethal substance in dead Proteus cells}

Extraction of endotoxins. The four strains, PR 1, PR 3, PR 23 and PR 24, were tested as soon as possible after isolation, maintained with the minimum of subcultivation, and passed through mice for retest. If the qualities of $\mathrm{Pr}$. vulgaris associated with virulence are similar to those of the $S$ form of other Gram-negative bacilli of the Bacterium, Shigella and Salmonella groups, these procedures should have preserved the strains in their original virulent state. With variation to an avirulent state associated with loss of characteristic and perhaps toxic antigens, it was possible that toxicity might change greatly during artificial subculture.

Large quantities of bacteria were therefore harvested as soon as possible after the virulence tests, using as seed the primary stock stab cultures made from the heart blood of mice dying of Proteus infection. The toxicity of cultures killed by heating for $90 \mathrm{~min}$. at $60^{\circ}$, and by precipitation from the culture medium by acetone, proved to be similar. Two to three-days' growth from nutrient agar in Roux bottles at $37^{\circ}$ was accordingly washed off with $\mathbf{0 . 8 5} \%$ saline, and precipitated with 3 vol. acetone, resuspended for 2 days in pure acetone, spun and suspended for $8 \mathrm{hr}$. in anhydrous ethyl ether and the spun deposit from the ether dried rapidly in vacuo. The rapid evacuation of the desiccator produced a crust of dried bacilli on the ether-wet deposit, and a few minutes later the superficially dry mass exploded to produce a fine, readily manipulable bacterial powder that could be stored indefinitely.

The toxicity of suspensions of virulent PR 1, killed by heating to $55^{\circ}$, by ethanol, by $0.1 \%$ formalin and by weak hydrochloric acid, were compared; they were equally toxic, weight for weight, as judged by a coarse titration. That is, there was no evidence of a grossly labile toxin destroyed at $60^{\circ}$ or by acetone.

Trypsin and toxicity of Proteus cells. By analogy with Salmonella typhimurium (Raistrick \& Topley, 1934) the predominant toxic substance in Proteus vulgaris should resist tryptic digestion and be liberated from the cells by it. The acetone-killing of cultures was adopted with this end in view. The limited acetone treatment in preparing the stock bacterial powder rendered the cells moderately susceptible to trypsin, but for complete and a more rapid digestion, continuous extraction of the bacterial powder with hot acetone (cf. Douglas \& Fleming, 1921) for $24 \mathrm{hr}$. in a reflux condenser, which removed a trace of yellow oily material, was necessary. Suspensions of acetone-killed cells of each of the four strains, $2 \mathrm{mg}$. $/ \mathrm{ml}$. of distilled water, were treated under toluene with a preparation of commercial trypsin (British Drug Houses Ltd.) $0.1 \mathrm{mg}$. to each $\mathrm{ml}$. of suspension for 2 days at $37^{\circ}$, the $\mathrm{pH}$ being maintained at $8 \cdot 3-8 \cdot 5$ by twice daily additions of $\mathrm{NaOH}$. An equal quantity of trypsin was

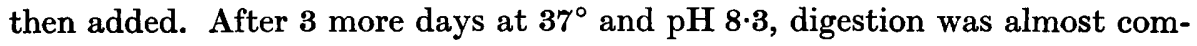


plete, with a translucent yellowish supernatant fluid and a little amorphous cell debris. Suspensions without trypsin were maintained under toluene for 5 days at $37^{\circ}$ at $\mathrm{pH} 8 \cdot 3$. For each strain, the volumes of digested and undigested suspension were made equal, and the LD 50 of the digests determined in relation to that of the starting material. The figures for PR3 (Table 3) exemplify the four results, which were:

$\begin{array}{cc}\begin{array}{c}\text { Strain } \\ \text { PR }\end{array} & \begin{array}{c}\text { Ratio of LD50 } \\ \text { digest/cells }\end{array} \\ 1 & 0 \cdot 54 \\ 3 & 1 \cdot 31 \\ 23 & 0 \cdot 96 \\ 24 & 1 \cdot 03\end{array}$

Table 3. The LD50 of acetone-killed suspensions of PR3, before and after tryptic digestion

\begin{tabular}{|c|c|c|}
\hline \multirow{2}{*}{$\begin{array}{c}\text { Dose } \\
\text { (mg. of original } \\
\text { dry bacilli) }\end{array}$} & \multicolumn{2}{|c|}{ No. mice dying/group injected with } \\
\hline & Untreated bacilli & Digested bacilli \\
\hline $\begin{array}{r}15.00 \\
5.00\end{array}$ & $\begin{array}{l}6 / 6 \\
6 / 6\end{array}$ & $\begin{array}{l}6 / 6 \\
4 / 6\end{array}$ \\
\hline 1.66 & $1 / 6$ & $2 / 6$ \\
\hline 0.55 & $0 / 6$ & $2 / 6$ \\
\hline LD50 & $2.49 \mathrm{mg}$. & $1.90 \mathrm{mg}$. \\
\hline
\end{tabular}

The limits of error of the ratios were large, and there is no significant alteration in toxicity by digestion, though the twofold decrease in toxicity of PR 1 is suggestive. It is possible that in any one digestion, digestion might destroy one toxin and liberate an equitoxic amount of another, but such a coincidence is unlikely to occur in three instances, and it appears that the endotoxin of PR3, PR23 and PR 24, like that of Salmonellatyphi-murium, is resistant to tryptic digestion. On the other hand, trypsin may have destroyed some toxin in PR1.

Centrifugation of the digests deposited considerable amounts of material. The distribution of toxicity between the deposit and the remaining soluble substances was measured in PR 1 and PR23. For each strain, a batch of dried cells was suspended in water, half the suspension being incubated under toluene at $\mathrm{pH} 8 \cdot 5$, and half digested with trypsin under the same conditions. The solids in the digest were spun out at 3000 r.p.m., leaving a turbid fluid from which a translucent gel was deposited at 18,000 r.p.m., or at 3000 r.p.m. after treatment of the fluid with $10 \%$ by weight of ethanol. This gel was amorphous under $\times 1000$ magnification, but on suspension in water gave a slightly turbid, shimmering suspension that precipitated specifically with O-antisera. For the toxicity test, all the solids precipitated by treatment of the digest with 0.14 vol. ethanol and washed with water containing $10 \%(w / w)$ ethanol, were used (insoluble). The weight of material in 'insoluble' and soluble fractions was determined; and the recovery of toxic substances estimated (Table 4). Most of the toxin was in the soluble fraction, though tryptic digestion and perhaps the mild ethanol treatment had in each case destroyed about onethird of the toxicity. 


\section{The mouse pathogenicity and toxicity of Proteus vulgaris 313}

Table 4. The toxicity of tryptic digest of Proteus bacilli soluble $(S)$ and insoluble $(I)$, and untreated bacilli

\begin{tabular}{|c|c|c|c|c|}
\hline Strain & Material & $\begin{array}{l}\text { LD 50 } \\
\text { (mg.) }\end{array}$ & $\begin{array}{c}\text { Total } \\
\text { weight } \\
\text { material } \\
(\mathrm{mg} .)\end{array}$ & $\begin{array}{c}\text { Recovery of } \\
\text { toxic substances } \\
(\%)\end{array}$ \\
\hline PR 1 & $\begin{array}{l}\text { Untreated } \\
\text { Soluble } \\
\text { Insoluble }\end{array}$ & $\begin{array}{l}1 \cdot 68 \\
2 \cdot 80 \\
7 \cdot 01\end{array}$ & $\begin{array}{r}612 \\
620 \\
90\end{array}$ & $\begin{array}{c}\left.\begin{array}{c}(100) \\
64 \cdot 0 \\
3 \cdot 5\end{array}\right\} 67 \cdot 5\end{array}$ \\
\hline PR 23 & $\begin{array}{l}\text { Untreated } \\
\text { Soluble } \\
\text { Insoluble }\end{array}$ & $\begin{array}{l}3 \cdot 00 \\
4 \cdot 63 \\
4 \cdot 07\end{array}$ & $\begin{array}{r}601 \\
616 \\
80\end{array}$ & 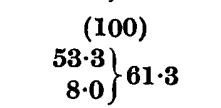 \\
\hline
\end{tabular}

Ethanol fractionation of tryptic digests. Raistrick \& Topley (1934) precipitated the typhi-murium endotoxin from their tryptic digests by $68 \%$ by weight of ethanol. Dried cells (3 g.) of each of the four Proteus strains in $600 \mathrm{ml}$. water were digested by two $75 \mathrm{mg}$. lots of trypsin. After 5 days at $37^{\circ}$ the digests were concentrated at $45^{\circ}$ to $120 \mathrm{ml}$. and solid matter ('insoluble' fraction FI) spun off at 18,000 r.p.m. The solids were washed and the washings added to the fluid, which was then concentrated to $40 \mathrm{ml}$., brought to $\mathrm{pH} 7 \cdot 0$, and mixed with $68 \%$ by weight of ethanol. The precipitate (F 68) was removed, and the weight of added ethanol brought to $90 \%$. After removal of the precipitate (F90) the liquor was finally treated with an excess of acetone and ethyl ether $(80 \%+20 \%, v / v)$, to obtain the FAE fraction. All the precipitates were washed with acetone and dried in vacuo over $\mathrm{H}_{2} \mathrm{SO}_{4}$ and $\mathrm{NaOH}$ pellets. FI and F 68 were fine white powders, but both F90 and FAE were yellowish, pasty and deliquescent. From the $3 \cdot 3 \mathrm{~g}$. of starting material (cells + trypsin) 85-95 \% of solids were recovered (Table 5), the yields of F68 lying between $24 \cdot 8$ and $30 \cdot 1 \%$.

Table 5. Percentage yields from fractionation with $68 \%$ (w/w) and $90 \%$ ethanol, and an acetone-ether miature

\begin{tabular}{|c|c|c|c|c|c|}
\hline \multirow[t]{2}{*}{ Fraction strain } & $\ldots$ & PR 1 & PR3 & PR23 & PR 24 \\
\hline & & \multicolumn{4}{|c|}{ Yields (\%) } \\
\hline $\begin{array}{l}\text { F1 } \\
\text { F68 } \\
\text { F90+FAE }\end{array}$ & & $\begin{array}{r}6.4 \\
24.8 \\
54.0\end{array}$ & $\begin{array}{r}8 \cdot 2 \\
27 \cdot 4 \\
56 \cdot 2\end{array}$ & $\begin{array}{r}8 \cdot 3 \\
28 \cdot 6 \\
55 \cdot 1\end{array}$ & $\begin{array}{l}10 \cdot 4 \\
30 \cdot 1 \\
54 \cdot 5\end{array}$ \\
\hline Recovery of solids & & $85 \cdot 2$ & $91 \cdot 8$ & $92 \cdot 0$ & $95 \cdot 5$ \\
\hline
\end{tabular}

Properties of the F68 fraction. Though, especially in PR1, up to half the toxicity in dried cells of Proteus vulgaris is destroyed or lost during digestion and ethanol fractionation, the $\mathrm{F} 68$ fraction nevertheless appears to be a representative though an impure sample of the endotoxin of Pr. vulgaris. First, the yield was similar from all recently isolated strains; from the twenty-one strains thus fractionated, the yield lay between $24 \cdot 1$ and $35.7 \%$, with an average of $30.2 \%$. Secondly, the LD50 of F68 prepared in parallel from PR1, PR3, PR 23 and PR24, were respectively $1 \cdot 94,1 \cdot 63,2 \cdot 41$ and $3 \cdot 12 \mathrm{mg}$. which are 
roughly of the same relative magnitudes as the toxicities of the heat-killed cells reckoned as dry weight of the cells $(0.95,1 \cdot 23,2 \cdot 73$ and $2.91 \mathrm{mg}$., Table 2$)$. Thirdly, their toxicity and precipitability by specific $\mathrm{O}$-antisera were, in comparison with other fractions, roughly parallel.

Finally, the immunological specificity of the F68 fractions was paralleled by that of the living bacilli, as regards serological reactions and immunizing power. The $O$ antigen of PR 1 was distinct from those of PR3, PR 23 and PR 24; PR 23 and PR24 were identical, but PR3, though closely related, was not identical with them (Belyavin, Miles \& Miles, 1951). When cross-testing the survivors of many virulence and toxicity tests of these strains with homologous or heterologous living bacilli, it was observed that the whole cells of PR 3, PR 23 and PR 24 were equally good in immunizing against infection by any one of the strains, whereas there was little cross-immunity between PR 1 and the other three.

The F68 fractions behaved similarly. In one test, the F68 of PR 1 in intraperitoneal doses of as little as $1 \mu \mathrm{g}$. conferred a solid immunity against infection by two LD 100 of living PR 1 given 1 week later (Table 6a). Similar doses were also effective, though less so in another test (Table $6 b$ ) against $c$. LD90 of PR 1, and ineffective against $c$. LD90 of PR3, both given 18 days after immunization. The specificity was, however, comparative, not absolute; large doses of $\mathbf{F} 68$ from PR 1 gave some protection against PR 3 infection and the $\mathbf{F} 68$ of all four strains could elicit hypersensitive (allergic) reactions in the skin of rabbits hyperimmunized with any one of them.

Table 6. Immunizing power of the $F 68$ fraction of strain $P R 1$

\begin{tabular}{|c|c|c|c|c|}
\hline \multirow{3}{*}{$\begin{array}{c}\text { Immunizing } \\
\text { dose } \\
(\mu \mathrm{g} .)\end{array}$} & \multicolumn{4}{|c|}{ Deaths after infection by } \\
\hline & \multicolumn{2}{|c|}{ PR 1} & \multicolumn{2}{|c|}{ PR3 } \\
\hline & $\begin{array}{c}\text { Millions } \\
\text { of organisms }\end{array}$ & $\begin{array}{l}\text { No. mice } \\
\text { dying/group }\end{array}$ & $\begin{array}{l}\text { Millions } \\
\text { of organisms }\end{array}$ & $\begin{array}{c}\text { No. mice } \\
\text { dying/group }\end{array}$ \\
\hline 25 & 305 & $0 / 10$ & - & - \\
\hline 5 & 305 & $0 / 10$ & - & - \\
\hline 1 & 305 & $0 / 10$ & - & - \\
\hline o & 305 & $10 / 10$ & - & - \\
\hline o & 61 & $2 / 10$ & - & - \\
\hline $\mathbf{0}$ & 12 & $1 / 10$ & - & - \\
\hline $50 \cdot 0$ & 800 & $1 / 10$ & 775 & $10 / 10$ \\
\hline $5 \cdot 0$ & 800 & $4 / 10$ & 775 & $8 / 10$ \\
\hline 0.5 & 800 & $4 / 10$ & 775 & $9 / 10$ \\
\hline 0.0 & 800 & $9 / 10$ & 775 & $9 / 10$ \\
\hline
\end{tabular}

\section{DISCUSSION}

There have been a number of attempts to measure the mouse-virulence of Pr. vulgaris (e.g. Yacob, 1932) of human origin, but the results are mainly crude, like the observation that whereas $1 \mathrm{ml}$. of an overnight culture was fatal, $\mathbf{0 \cdot 2} \mathrm{ml}$. was not. My titrations are less crude, though large numbers of mice would be needed to distinguish even tenfold differences in LD 50 in a single 
comparison; and unexplained variability in Proteus strains makes it likely that an LD50 so obtained would not be consistently observed with repetition of the test. Nevertheless, it is clear in general that the mouse-virulence of Pr. vulgaris is low, but that some strains, soon after isolation at least, have a low LD 50 that suggests invasive powers above the average.

Most of the tests were made in 1937, as part of an investigation interrupted by the 1939-45 war, and cultures were not preserved in the dry state soon after isolation. With the better current methods of storing cultures, it might be possible to determine the factors responsible for the greater invasiveness of some strains. The relatively brutal analysis to which the strains were subjected-heator acetone-killing, digestion, and fractionation with organic solvents-is likely to have revealed little but stable components of the bacillary cells that might be associated with virulence; but there was no indication of a toxin associated with the more virulent strains.

Previous studies of the toxins of Pr. vulgaris have been mainly of culture filtrates, though Triffterer (1943) records that trichloroacetic acid extracts of Proteus X19 were toxic for mice, and that the toxicity was neutralized by the sera of typhus patients.

My fractionation of endotoxic substances in the Proteus cells is only preliminary, and much remains to be investigated. The $\mathbf{F} 68$ fractions, which by crude tests appeared to contain a large proportion of lipo-polysaccharide, are probably similar to the alkali-labile O-receptor of White (1933), the P-substance of Castaneda (1935); the glyco-lipid antigen of Ciuca, Mesrobeanu, Badenski \& Muteanu (1938), all of which were obtained from Proteus X19; and to the T-1 fraction that Bendich \& Chargaff (1946) obtained after removing from tryptic digests all material sedimentable by high-speed centrifugation. All these fractions appeared to be characteristic of Proteus, as distinct from rickettsial cells, and it is noteworthy that limited tests suggest that most of the toxicity of dead cells remains in this $\mathbf{F} 68$ fraction (Table 4); much less is present in the 'insoluble' fractions corresponding to Bendich and Chargaff's T-2, the immunologically distinct antigen that characterizes both Proteus and rickettsial cells.

\section{REFERENCES}

BARritr, M. M. (1936). The intensification of the Voges-Proskauer reaction by the addition of alpha-naphthol. J. Path. Bact. 42, 441.

Belyavin, G., Miles, E. M. \& Miles, A. A. (1951). The serology of fifty-one strains of Proteus vulgaris. J. gen. Microbiol. 5, 178.

Bendich, A. \& Chargaff, E. (1946). The isolation and characterization of two antigenic fractions of Proteus OX 19. J. biol. Chem. 166, 283.

Castaneda, M. R. (1935). The antigenic relationship between Bacillus proteus X-19 and Rickettsia. III. A study of the antigenic composition of the extracts of Bacillus proteus X-19. J. exp. Med. 62, 289.

Ciuca, M., Mesrobeanu, L., Badenski, A. \& Munteanu, G. (1938). Sur la structure antigénique des souches de Proteus $\mathrm{X}$ et sur le rôle de leur antigène glucidolipidique dans la réaction de Weil-Félix. C.R. Soc. Biol., Paris, 127, 1414.

Douglas, S. R. \& Fleming, A. (1921). On the antigenic properties of acetoneextracted bacteria. Brit. J. exp. Path. 2, 131. 
Gaddum, J. H. (1933). Methods of Biological Assay depending on a Quantal Response. Spec. Rep. Ser. med. Res. Coun., Lond., no. 183.

Mrues, A. A. \& Misra, S. S. (1938). The estimation of the bactericidal power of the blood. J. Hyg., Camb., 38, 732 .

Raistrick, H. \& Topley, W. W. C. (1934). Immunizing fractions isolated from Bact. aertrycke. Brit. J. exp. Path. 15, 113.

Topley \& Wilson's Principles of Bacteriology and Immunity (1946). 3rd ed. Wilson, G. S. \& Mules, A. A. London: Arnold.

Triffterer, T. von (1943). Zusammenhang zwischen der Weil-Felixschen Reaktion und der Präzipitation des O-Antigens des Proteus Bazillus, X 19. Z. ImmunForsch. 104, 41.

White, P. B. (1933). The O-receptor complex of B. proteus X-19. Brit. J. exp. Path. $14,145$.

YACoB, M. (1932). Studies of the genus Proteus. Part I. A cultural and serological study of certain strains of the Proteus group. Indian. J. med. Res. 19, 787.

(Received 26 June 1950) 